Bartın Üniversitesi

Eğitim Fakültesi Dergisi

Cilt 6, Sayı 1, s. 29-47, Subat 2017

BARTIN - TÜRKIYE

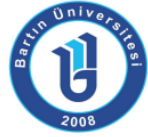

ISSN: 1308-7177
Bartin University

Journal of Faculty of Education

Volume 6, Issue 1, p. 29-47, February 2017

BARTIN - TURKEY

\title{
Okul Öncesi Sınıflarında Çocuğun Katılım Hakkının Çocukların ve Öğretmenlerin Görüşlerine Göre İncelenmesi
}

Kevser TOZDUMAN YARALI, Arş. Gör., Kırklareli Üniversitesi Sağlık Yüksekokulu, kevserizmir@gmail.com

F. Abide GÜNGÖR AYTAR; Prof. Dr., Gazi Üniversitesi Eğitim Fakültesi, abidegungor@gmail.com

Öz: Araştırmada, okul öncesi eğitim uygulamalarında çocuğun katılım hakkının öğretmen ve çocukların görüşlerine göre incelenmesi amaçlanmıştır. Araştırmada nitel model ve durum deseni kullanılmıştır. Araştırmaya Kırklareli ve Ankara merkezdeki iki okul öncesi eğitim kurumunda görev yapan on öğretmen ve altı yaş grubundaki on çocuk katılmıştır. Veriler, öğretmenlerden bireysel görüşmeler yoluyla toplanmış olup, çocuklardan ise ikili odak grup görüşmeleri yapılarak elde edilmiştir. Araştırmadan elde edilen veriler katılım niteliklerinin oluşturduğu kategorilere göre kodlanmış ve çalışmada betimsel analiz kullanılmıştır. Araştırmanın geçerliğini artırmak için çalışmada öğretmen ve çocukların görüşlerine yer verilirken, güvenirliği artırmak için öğretmenlerin görüşlerine ait bir tablo ile çocukların görüşlerine ait tablo kodlayıcı güvenirliği yapılarak ikinci bir araştırmacı tarafından da kodlanmıştır. Araştırmanın sonucunda çalışma grubundaki öğretmenlerin, çocuğun katılım hakkı konusunda yeterli bilgiye sahip olmadıkları ortaya çıkmıştır. Bunun yanında, çalışma grubundaki öğretmenlerin, çocuğun katılım hakkını sağlamaya yönelik yaptıkları uygulamalarla, çocukların katılım hakkını sağlamalarının yanında ihlal ettikleri de görülmüştür. Çocukların görüşleri değerlendirildiğinde ise, çocukların daha çok, serbest zaman etkinliklerinin süresinin artması, etkinliklere gönüllü katılım ve etkinliklerin daha az yapılandırılması yönünde talepleri olduğu belirlenmiştir.

Anahtar Kelimeler: katılım hakkı, okul öncesi eğitim, çocuk hakları, odak grup görüşmesi, öğretmen görüşleri

\section{Investigate the Participation Rights of Children into the Preschool Classes through Teachers and Children Views}

Abstract: The aim of this study is to investigate the participation rights of children into the preschool education activities through teacher and child views. The study was designed through a qualitative approach using case study design. The participants of this study are composed of ten teachers and ten children who were at the six age group at two preschool education institutions in Kırklareli and Ankara. The data were collected through individual interviews with teachers while the children participated in focus group interviews which were carried out with two children in each group. Since the data collected in this study were coded based on the participation qualifications of children; descriptive analysis method was used. In order to increase the validity of the study the student and teacher views were included; to obtain interrater reliability some of the data were coded by a second researcher. At the end of the study, it has been revealed that teachers do not have enough information about the participation rights of children. Moreover, teachers' applications towards providing the participation right for children were both inhibiting and increasing their participation rights. When children's views were investigated, their demands were towards more leisure time activities, voluntary participation in the activities, and less structured activities.

Key Words: children's rights to participation, preschool education, children rights, focus group interviews, teachers' opinions 


\section{GíRiş}

Çocuk hakları, insan hakları kavramının içinde ele alınması gereken bir konu olmakla birlikte, dünya üzerindeki tüm çocukların sahip olduğu, eğitim, sağlık, barınma, fiziksel, psikolojik veya cinsel sömürüye karşı korunma gibi hakların tümünü tanımlamakta kullanılan evrensel bir kavramdır. Birleşmiş Milletler Genel Kurulu tarafından 20 Kasım 1989 yılında benimsenen sözleşme ile çocuk haklarının korunması amaçlanmış ve taraf devletlerin sözleşme maddelerine kesinlikle uymaları gerektiği hükme bağlanmıştır (Acar, 2003; Yıldırım Doğru, 2012). Modern dünyada çocuk bir "kişi" olarak kabul edilmeye başlanmıştır (Alderson, 2000). Çocuklar artık yarının insanları değil, bugün de saygı ve duyarlılıkla davranılması gereken ciddi haklara sahip insanlar olarak görülmektedirler. Kuşkusuz 1989 BMS, bugünkü çocuk politikasının belirlenmesinde ve çocuğun katılım hakkına yönelik girişimlerin temeli niteliğindedir (Woodhead, 2010). Kişisel kimlik, eğitim, sevgi, ahlak, maddi güvenlik, oyun ve rekreasyon, diğerleri için hoşgörü ve saygının geliştirilmesi ve çocuğun yüksek yararı gibi birçok unsuru içerdiğinden, BMÇHS, çocuk hakları tarihinin kilometre taşı niteliğindedir (Hart ve Hart, 2014). Sözleşme çocukların karşılaşabilecekleri tüm sorunlara değinir. Sözleşmedeki maddeler dört temel ilke doğrultusunda belirlenmiştir. Bunlar, yaşama-gelişme, eşitlik-ayrım gözetmeme, çocuğun yüksek yararı ve çocuk katılımıdır (Erbay, 2013).

Çocuğun katılım hakkına dair sözleşmenin 12. Maddesi şöyledir: "Taraf Devletler, görüşlerini oluşturma yeteneğine sahip çocuğun kendini ilgilendiren her konuda görüşlerini serbestçe ifade etme hakkını bu görüşlere çocuğun yaşı ve olgunluk derecesine uygun olarak, gereken özen gösterilmek suretiyle tanırlar."(Unicef, 2004). Katılım hakkını düzenleyen 12. madde, kendileri ve başkaları için amaçlanan hedefleri hesaba katmaksızın çocuklara tek başına karar alma hakkı tanımaz. Katılım hakkı, çocukların hakların öznesi bir birey olduklarının kabulünü ve seslerinin duyulmasını engelleyen geleneksel tutumların değiştirilmesini amaçlar (Akyüz, 2013).

BM Çocuk Hakları komitesine göre, çocuğun katılım hakkının teşvik edilmesini gerektiren yerlerden biri de okul ortamıdır (Erbay, 2013). Katılım hakkı, çocukların edilgen birer alıcılar oldukları geleneksel yaklaşımdan uzaklaşıp, bunun yerine çocukların hayatlarını etkileyen kararları almada aktif olarak rol almaları gerekliliğini savunmaktadır (Lansdown, 2005). Çocukların katılımını sağlamak için çocukların düşüncelerini, fikirlerini ve duygularını açıkça ve dürüstçe paylaşmaları sağlanmalıdır. Çocukların etkin katılım gerçekleştirebilmeleri için onlara fırsat ve sorumluluk vermek ve çocukları desteklemek gerekmektedir. Çocuklara karar alma süreçlerinde roller ve sorumluluklar vermek kazanacakları deneyimler açısından önem taşır (Stehphenson vd., 2004; Akt. Özer, 2013). Sözleşme, çocukların görüşlerini serbestçe ifade edebilmelerine ilişkin herhangi bir yaş sınırlaması getirmemiştir, sadece "görüşlerini oluşturma yeteneğine sahip" çocuk ifadesini kullanmıştır. Bu nedenle, çocuğa kendi görüşlerini oluşturacak durumda olmadığının açık biçimde belli olduğu durumlar haricinde bu hakkı kullanma imkanı tanınmalıdır. Bu şekilde, çocuğun yaş nedeniyle bu hakkın kapsamı dışında bırakılması önlenmiştir (Akyüz, 2001). Bununla birlikte sözleşmenin başka maddeleri de çocuğun düşünme ve ifade özgürlüğüne vurgu yapmışlardır. "Çocuk düşüncesini özgürce açıklama hakkına sahiptir...(Md.13). Taraf devletler, çocuğun düşünce, vicdan ve din özgürlükleri hakkına saygı gösterirler...(Md.14). (Unicef, 2004). Çocuk haklarına dair sözleşmede, hak sahibi kişiler olarak en küçük çocukların dahi yaş ve olgunluk düzeyine göre görüşlerini bildirme hakkı olduğu vurgulanmakta, “...görüşlerini oluşturma yeteneğine sahip çocuk ifadesi kullanılmaktadır. Burada dikkat edilmesi gereken nokta, çocuğun yazılı ve sözlü dil kurallarını öğrenmeden önce bile duygu, düşünce ve isteklerini çeşitli yollarla ifade edebilecekleridir (ÇHK, 2009; İnal, 2014; Mamur Işıkçı, 2015). Yapılması gereken, koşulların 
çocuğun yaşına ve olgunluk düzeyine göre ayarlanmasıdır. Çocukların üzerinde, görüşlerini serbestçe ifade etmelerini engelleyici veya kendilerini kullanılıyor hissetmelerine yol açabilecek baskı, kısıtlama veya etki olmaması gerektiğidir (Özdemir ve Ruhi, 2012; Unicef, 2009).

Çocuğun katılım hakkı Genel Yorum No. 12'de (2009) çocuğun/çocukların görüşlerinin alındığı ve katılımının sağlandığı tüm süreçlerin taşıması gereken nitelikler belirtilmiştir:

Şeffaf ve bilgilendirici niteliği: Çocuklara görüşlerini özgürce ifade etme ve görüşlerinin dikkate alınması hakları ile katılım sürecinin kapsamı, amacı ve olası etkisine ilişkin, tam erişilebilir, farklılıklara duyarlı ve yaşlarına uygun bilgi sunulmalı.

Gönüllü niteliği: Çocuklar görüşlerini ifade etmeye asla zorlanmamalı, katılımlarını her aşamada sona erdirebilecekleri konusunda bilgilendirilmeli.

Saygılı niteliği: Çocukların görüşleri saygıyla karşılanmalı, sosyoekonomik ve kültürel farklılıklara duyarlı olunmalı.

Ilgili niteliği: Çocukların görüşlerinin alınacağı konular, çocukların yaşamları ile ilgili olmalı; çocuklara bilgi ve becerilerini kullanma olanağı verilmeli.

Çocuk dostu niteliği: Ortamlar ve yöntemler çocukların yaşlarına ve gelişen kapasitelerine göre uyarlanmalı.

Kapsayııı niteliği: Katılım içermeci olmalı, tüm çocukların eşit katılımı sağlanmalı; dezavantajı grupların bireylerin katılımını sağlayacak olanaklar geliştirilmeli.

Eğitim ile desteklenmiş niteliği: Yetişkinler ve çocuklar, birlikte ortaklaşa ve etkin biçimde çalışabilmek için hazırlanmalı, güçlendirilmeli.

Güvenli ve riske karşı duyarlı niteliği: Çocukların görüşlerini ifade etmeleriyle oluşabilecek risklerin azaltılması için gerekli önlemler alınmalı; çocuklar gereksinim duyduklarında yardım için nereye gitmeleri gerektiği konusunda bilgilendirilmeli.

Hesap verebilir: Çocuklar, görüşlerinin nasıl yorumlandığına ve kullanıldığına ilişkin bilgilendirilmeli; katılımlarının elde edilen sonuçları nasıl etkilediği konusunda açık geribildirim alabilmeli (BM ÇHK, 2009; Tüzün ve Sarışık, 2015).

Çocuk katılımı, eğitim ve öğretim süreçlerinin her alanı ve aşamasıyla yakından ilişkilidir. Yerel düzeyde eğitim politikaları tasarlanmasından, okul düzeyinde kuralların belirlenmesi ve öğrenme-öğretme süreçlerine kadar çocukların söz sahibi olmaları gerekmektedir (Tüzün ve Sarışık, 2015). Fiziksel çevrenin düzenlenmesi, planlanması, tasarlanması ve yönetilmesi çocukların katılım hakkı için ideal bir alan oluşturur (Hart, 2007). Okul ortamında katııım hakkının sağlanması için demokratik eğitim ilkesinin hayata geçirilmesi ve eğitim sürecinde kullanılan yöntemlerin öğrenci merkezli olması gerekir. Demokrasinin ise anlatılan bir olgu değil, yaşanan bir süreç olması gerekmektedir (Akyüz, 2013). Çocukların demokratik okul kültürü bağlamında en çok desteğe ve geliştirilmeye ihtiyaç duydukları alanın sınıfları ve okulları ile ilgili konularda yöntem ve karar mekanizmalarına katılım, inisiyatif ve sorumluluk alma olduğu söylenebilir (Demokratik okul kültürü projesi, 2013; Akt. Tüzün ve Sarışık, 2015). Çocuklara ne söyleyeceklerinin dikte edilmesi, çocukların yetişkinler tarafından yönlendirilmesi, katılımın bireysel ve tek seferlik bir etkinlik olarak uygulanması katılım karşıtı uygulamalar olarak ele alınır (Koran Güner, 2015). Çocukların katılımı, çocukların ihtiyaç duydukları şeyler konusunda bilgi sahibi olmayı, çocukları ilgilendiren kararların daha iyi bir ortamda alınmasını ve demokrasinin daha iyi anlaşımasını sağlar (Williams, 2004). Bir okul öncesi eğitim kurumunun nasıl olması gerektiği ve okul öncesi kurumlarında neler bulunması gerektiği V. Milli Eğitim Şurası'nda belirtilmesine karşın, birçok okulun bu yeterlilikleri karşılayamadığı görülmektedir (TED, 2007). 
Bu bağlamda araştırmanın amacı, okul öncesi eğitim kurumlarında yer alan sınıflardaki uygulamaları katılım hakkı niteliklerine göre değerlendirmektir. Buna göre aşağıdaki sorulara yanıt aranmıştır:

$\checkmark$ Okul öncesi öğretmenlerinin çocuğun katılım hakkının ne olduğuna ilişkin görüşleri nelerdir?

$\checkmark$ Okul öncesi öğretmenlerinin görüşlerine göre, okul öncesi öğretmenlerinin çocuğun katılım hakkını sağlamaya yönelik uygulamaları nelerdir?

$\checkmark$ Okul öncesi öğretmenlerinin görüşlerine göre, okul öncesi öğretmenlerinin yaptıkları sınıf içi uygulamalarda, çocukların katılım hakkına yönelik ihlal ettikleri konular nelerdir?

$\checkmark$ Okul öncesi dönem çocuklarının görüşlerine göre, sınıf içi uygulamalarda kullanamadıklarını düşündükleri katılım hakları nelerdir?

\section{YÖNTEM}

\subsection{Araştırmanın Modeli}

Nitel modelde tasarlanan çalışmada durum deseni kullanılmıştır. Durum deseninde bir veya birkaç durumun detaylı bir şekilde incelenmesi amaçlanır. Bu çalışmalar, gerçek yaşam bağlamında bir bütün içerisindeki bir durumu içerir (Johnson ve Chiristensen, 2014). Nitel durum çalışmaları da diğer araştırma türlerinde olduğu gibi anlayış arayışı içerisindedir. Bu çalışmalarda birincil veri toplama ve analiz aracı, araştırmacının kendisidir (Merriam, 2015). Durum araştırmaları süreç odaklıdır. Belirli bir sürecin kendi ortamı içinde çalışılması ve odaklanılan soruna ilişkin veri toplanması söz konusudur (Yıldırım ve Şimşek, 2013). Bu araştırmada da durum çalışması kapsamında 10 öğretmen ve 10 çocuğun çocukların katılım hakkına ilişkin görüşleri incelenmiştir.

Durum çalışması yaparken izlenen aşamalar şöyledir: Araştırma sorularının geliştirilmesi, araştırmanın alt problemlerinin geliştirilmesi, analiz birimini saptanması, çalışılacak durumun belirlenmesi, araştırmaya katılacak bireylerin seçimi, verilerin toplanması ve toplanan verinin alt problemlerle ilişkilendirilmesi, verilerin analiz edilmesi ve yorumlanması ve durum çalışmasının raporlaştırılmasıdır (Yıldırım ve Şimşek, 2013). Bu araştırmada da, bu sıralama izlenmiş̧ir.

\section{2. Çalışma Grubu}

Araştırmanın çalışma grubunu Kırklareli merkezdeki bir anaokulu ile ve Ankara merkezde bulunan bir anaokulu oluşturmuştur. Araştırmanın verileri bu okullarda görev yapan on okul öncesi öğretmen ve altı yaş grubundaki on çocuktan toplanmıştır. Çalışma grubuna katılan öğretmenler ve çocuklar benzeşik (homojen) örnekleme yöntemine göre seçilmişlerdir. Buradaki amaç, küçük, benzeşik bir örneklem oluşturma yoluyla bir alt grubu tanımlamaktır. Çocukların ailelerinin yüksek bir eğitim düzeyine sahip olması (en az üniversite mezunu) ve her iki ilin merkezinde bulunan bir okulda görev yapan öğretmenlerin seçilmiş olması benzeşik özellikler göstermektedir (Yıldırım ve şimşek, 2013). Patton (2014), benzeşik örnekleme yoluyla oluşturulmuş gruplardan odak grup görüşmeleri yoluyla etkili bir biçimde veri toplanabileceğini belirtir. Veriler 21.03.2016-15.04.2016 tarihleri arasında toplanmıştır. Araştırmaya, ailelerinden izin alınan, görüşme yapmak için gönüllü ve istekli olan çocuklar dahil edilmiştir. Görüşme yapmak istemeyen çocuklar çalışma kapsamına alınmamıştır. Öğretmenlerle yapılan görüşmelerde de gönüllülük esas alınmıştır. 


\subsection{Veri Toplama Araçları}

$\mathrm{Bu}$ araştırmanın verileri öğretmenlerden yarı-yapılandırımış görüşme tekniği kullanılarak, çocuklardan ise odak grup görüşmesi yoluyla toplanmıştır. Odak grup görüşmeleri, özgün cevaplar üretme kaygısı taşımaz. Bir uzlaşma aranmadığı gibi katılımcıların mutlaka aynı fikirde olması da beklenmez. Grup görüşmelerinde katılımcıların olaylara başkasının penceresinden bakabildiği bir durumda sağlıklı verilere ulaşmak amaçlanır (Patton, 2014). Yarıyapılandırılmış görüşmelerde ise sorular önceden belirlenerek veriler bu yolla toplanmaya çalışılır. (Merrriam, 2015; Karasar, 2002). Görüşme, bireylerin gözlenme imkânının olmadığı durumlarda araştırmacının bireylerin kendilerinin dışındaki dünyayı nasıl algıladıklarını ortaya koyma amacı ile yapılır (Merriam, 2015). Bu bağlamada öğretmenlere "Çocuğun katıım hakkı nedir size göre?, Çocuğun katılım hakkı nasıl sağlanmalıdır?, Çocukların katılım haklarını sağlamaya yönelik olarak siz etkinlikleri uygularken nelere dikkat ediyorsunuz? vb. altı soru sorulmuştur. Çocuklarla yapılan grup görüşmelerinde ise çocuklara "Sen okulda/sınıfta nelere karar verebiliyorsun, nelere karar veremiyorsun?, Sınıfta en çok neyi/ne yapmayı seviyorsun, neyi/ne yapmayı sevmiyorsun?, Ögrretmenler ne yapıyorlar, sence ne yapmalılar" vb. beş soru sorulmuştur. Sorular oluşturulurken açık uçlu olmasına, yönlendirici olmamasına, çalışma grubu tarafından anlaşılabilir olmasına dikkat edilerek hazırlanmıştır. Çocuklarla yapılan görüşme esnasında dikkati dağılan çocukların tekrar konuya dönmelerini sağlamak için sorular tekrar hatırlatılarak neler düşündükleri sorulmuştur. Oluşturulan sorular görünüş ve kapsam geçerliğinin sağlanması için nitel araştırmalar konusunda doktora düzeyinde ders veren bir uzman tarafından incelenmiş ve uzman görüşüne göre sorular üzerinde gerekli düzeltmeler yapılmıştır.

\subsection{Verilerin Toplanması}

Araştırmanın verilerinin toplanmasında öğretmenlerin ve çocukların görüşlerine başvurulmuştur. Bütün görüşmeler aynı araştırmacı tarafından gerçekleştirilmiştir. Öğretmenlerle yapılan görüşmeler bireysel olarak gerçekleştirilmiş olup görüşmeler kayıt altına alınmıştır. Ses kaydı yapılmasını istemeyen öğretmenlerin görüşleri görüşme esnasında araştırmacı tarafından not tutularak kaydedilmiştir. Her öğretmen ile yapılan görüşme ortalama 15 dakika sürmüştür.

Çocuklarla yapılan görüşmeler ise odak grup şeklinde gerçekleştirilmiştir. Çocuklar görüşmelere ikişerli olarak alınmıştır. Yani her görüşme oturumu, yakın arkadaş olan iki çocuk ile gerçekleştirilmiştir. Pilot uygulama için ilk olarak tek çocukla görüşme yapılmış, daha sonra yakın arkadaş olan iki çocuk ile görüşme gerçekleştirilmiştir. Pilot uygulama sonucunda grupla yapılan görüşmenin amaca daha uygun olduğu, çocukların kendilerini daha rahat ifade ettikleri ve konuşmayı sürdürmeye daha istekli oldukları tespit edilmiştir. Pilot çalışmanın verileri, araştırma verilerine dahil edilmemiştir. Bununla birlikte yapılan tüm görüşmeler ikişerli grup şeklinde sürdürülmüştür. Her grupla görüşme ortalama 15 dakika sürmüştür. Odak grup görüşmeleri tümevarımcı bir yaklaşımla, olayları ve olguları doğal ortamları içinde betimleme, katılımcıların bakış açılarını anlama ve yansıtma üzerine odaklanan araştırma yaklaşımıdır (Yıldırım ve Şimşek, 2013). Odak grup görüşmelerinde önemli olan genellemelere gidecek bilgiye ulaşmak değil, karşııkı etkileşimlerle katılımcıların birbirlerinin zihinlerindeki duygu ve düşünceleri tetiklemesi, böylelikle de zengin bir bilgi akışı sağlamaktır. Bu şekilde katılımcıların görüşlerinin ve bakış açılarının betimlenmesi mümkün olmaktadır (Çokluk, vd., 2011).

Araştırmacılar çocuklarla yapılan görüşmelerin ikişerli ya da üçerli gruplar oluşturarak yapılmasını önermektedirler. Grup görüşmeleri etkileşime dayandığı için çocukların sorular üzerinde tartışmalarına, cevap verme konusunda desteklemelerine, detayları hatırlamalarına, 
cevapların doğruluklarının korunmasına katkı sağlar. Ayrıca, çocuklar birlikteyken kendilerini daha güçlü hissederler ve arkadaşlarının yanında daha rahattırlar (Einarsdottir, 2007; Mayall, 2000; Parkinson, 2001). Bazı kaynaklar odak grup görüşmeleri için ideal sayının dört-altı olduğunu belirtse de(Merrriam, 2015) okul öncesi dönem çocuklarıyla yapılan çalışmalarda çocukların dikkat süreleri ve gelişimsel özellikleri açısından daha küçük gruplarla çalışmanın daha etkili olduğu görülmüştür. Çocuklarla görüşme sırasında çocukların dikkatleri zaman zaman dağıımıştır. Bu durumda, araştırmacı ısrarla görüşmeye yönelik soru sormak yerine çocukların üzerinde konuştukları ifadeleri dinlemiş, ancak kendi görüşünü belirtmeden ek sorularla konuyu tekrar araştırmanın amacına yönlendirmiştir.

\subsection{Etik Konular}

Çalışma grubundaki öğretmenlerle yapılan görüşmeler sırasında, ses kaydı yapılmasını istemeyen öğretmenlerin ifadeleri not edilmiş olup, bundan dolayı not tutarak kayıt altına alınan görüşmeler yaklaşık beş dakika kadar daha uzun sürmüştür. Görüşme yapılan çocuklar gönüllülük esasına göre seçilmiştir. Görüşme yapılan çocukların ailelerinden izin alınmıştır. Çocuklara araştırmanın kapsamı genel hatlarıyla ifade edilmiş ayrıntı vermeden çalışmaya katkıda bulunmak isteyip istemedikleri sorulmuştur (aydınlatılmış onam). Çocukların yakın oldukları arkadaşları öğretmenlerine sorulmuş olup, çocukların karşılıklı onayları alındıktan sonra görüşmeye alınmışlardır. Çocuklarla görüşme esnasında dikkat dağıtıcı unsurlardan bağımsız, bir masa ve üç sandalyenin (iki dönebilen tekerlekli, bir normal) olduğu bir oda kullanılmıştır. Çocuklar odaya araştırmacının önünden alınmış olup çocuklara istedikleri yere istedikleri gibi oturabilecekleri söylenmiştir. Tüm çocuklar dönebilen tekerlekli sandalyeye oturmayı tercih etmiş ve bu durum onlara görüşme esnasında rahat hareket etme olanağı sağlamıştır (Bir çocuk görüşme esnasında ayaklarını masaya uzatmayı tercih etmiştir). Çocuklarla yapılan görüşmeler etik ilkeler gereği öğretmenlerle paylaşılmamıştır. Çocukların ve öğretmenlerin isimleri kullanılmamış, bunun yerine çocuklar için Ç1, Ç2 vb., öğretmenler içinde Ö1, Ö2 vb. kodlamalar kullanılmıştır.

\subsection{Verilerin Analizi}

Görüşme tekniği kullanılarak toplanan veriler betimsel analiz yoluyla değerlendirilmiştir. Betimsel analiz, elde edilen verilerin daha önceden belirlenen kategorilere göre özetlenmesi ve yorumlanması şeklinde tanımlanmaktadır. Betimsel analizin amacı, ham verilerin okuyucunun anlayabileceği, isterse kullanabileceği bir biçime sokulmasıdır. Betimsel analiz, analiz için bir çerçeve oluşturma, tematik çerçeveye göre verilerin işlenmesi, bulguların tanımlanması ve bulguların yorumlanması basamaklarından oluşmaktadır (Yıldırım ve şimşek, 2013). Veri toplamada birden fazla yöntemin kullanılması, yani çoklu veri kaynaklarından yararlanılması nitel araştırmalarda araştırmanın geçerliğini ve güvenirliğini artıran veri üçgenleme yöntemlerinden birisidir (Merriam, 2015; Creswell, 2014). Bu araştırmada çocuklar ve öğretmenler ile görüşme teknikleri birlikte kullanılarak veri çeşitlemesi yapılmıştır. Öğretmenlerin ve çocukların görüşleri, katılım hakkının uygulanmasını kolaylaştırmak ve nitelikli bir uygulama sağlamak için oluşturulan şeffaf ve bilgilendirici, gönüllü, saygllı, ilgili, çocuk dostu, kapsayıcı, güvenli ve riske karşı duyarlı kategorileri kullanılarak analiz edilmiştir (BMÇHK, 2009: Family Health International). Katılım hakkı ile ilgili nitelikler çocuklarla yapılan tüm uygulama süreçlerine uyarlanabilmektedir (Koran Güner, 2015). Toplanan tüm veriler betimsel analiz teknikleri kullanılarak analiz edilmiştir. Illk aşamada kodlama işlemi yapılmıştır. Kodlama kategorilerinin oluşturulmasında Çocuğun Katılım Hakkı Genel Yorum No .12'de (BM ÇHK, 2009) çocuğun/çocukların katıldığı tüm süreçlerin taşıması gereken katıımın nitelikleri kullanılarak betimsel analiz çerçevesi geliştirilmiştir. Bu çerçeveye göre öğretmenlerden elde 
edilen verilerin şeffaf ve bilgilendirici, gönüllü, saygılı, ilgili, çocuk dostu, kapsayıcı, güvenli ve riske karşı duyarlı ve hesap verebilir niteliklerine göre analiz edilmesine karar verilmiştir. Çocuklardan ulaşılan verilerin analizinde çocukların yanıtlarından ulaşılması mümkün olmayan güvenli ve riske karşı duyarlı niteliği kategoriden çıkartılmıştır. Eğitim ile desteklenmiş niteliği ise daha genel bir kavram olması ve başka uygulamalara gereksinim doğurduğu için hem öğretmenlerden hem çocuklardan ulaşılan verilerin analizinde kategori kapsamından çıkartılmışır.

Öğretmenler ve çocuklardan elde edilen veriler betimsel analiz yoluyla ayrı ayrı kodlanmış ve görüşme içerikleri de birer kod haline getirilmiştir. İki araştırmacı öğretmenlerin görüşlerine ait bir tablo ile çocukların görüşlerine ait tabloyu güvenirlik analizi yapmak amacıyla değerlendirmişlerdir. Güvenirlik analizi, biri çalışmayı yürüten araştırmacı, diğeri araştırmadan bağımsız çocuk gelişimi alanında bir uzman tarafından gerçekleştirilmiştir. Bu işlem için Kodlayıcılar Arası güvenirlik= [Görüş birliği/ (Görüş birliği + Görüş ayrılığı) X 100] formülünden (Miles ve Huberman, 2015) yararlanılarak gerçekleştirilmiştir. Bu işlem sonucunda güvenirlik yüzdesi \% 95 olarak hesaplanmıştır. Kodlayıcılar arasında görüş ayrılığına sebep olan katılım hakkının şeffaf bilgilendirici ve kapsayıcı niteliğine ait üç madde için ise uzlaşmaya varılmıştır. Kodlayıcı güvenirliği hesaplandıktan sonra diğer görüşmelerin betimsel analizleri araştırmacı tarafından yapılmışır. Ayrıca betimsel analizin kullanıldığı durumlarda görüşmelerin içeriğine yönelik doğrudan alıntılar vermek geçerlilik için önemli olduğundan (Yıldırım ve Şimşek, 2013), tablo sonunda öğretmenlerin ve çocukların görüşlerine de yer verilmiştir. Yapılan alıntılarda katılımcıların isimleri gizli tutulmuş, alıntılar Ö1, Ç2... biçiminde ifade edilmiştir.

\section{BULGULAR}

Aşağıdaki tabloda öğretmenlerin çocuğun katılım hakkının kapsamına ilişkin görüşlerine ait bulgulara yer verilmiştir.

Tablo 1

Öğretmenlerin, Çocuğun Katıım Hakkının Ne Olduğuna Yönelik Görüşlerinin Katılım Hakkı Niteliklerine Göre Analiz Edilmesi

\begin{tabular}{|c|c|c|c|c|c|c|c|c|}
\hline & \multicolumn{8}{|c|}{ Katılım Hakkı Nitelikleri } \\
\hline & $\begin{array}{l}\text { Şeffaf ve } \\
\text { bilgilendirici } \\
\text { niteliği }\end{array}$ & $\begin{array}{l}\text { Gönüllü } \\
\text { niteliği }\end{array}$ & $\begin{array}{l}\text { Saygılı } \\
\text { niteliği }\end{array}$ & $\begin{array}{l}\text { ilgili } \\
\text { niteliği }\end{array}$ & $\begin{array}{l}\text { Çocuk } \\
\text { dostu } \\
\text { niteliği }\end{array}$ & $\begin{array}{l}\text { Kapsayıcı } \\
\text { niteliği }\end{array}$ & $\begin{array}{l}\text { Güvenli } \\
\text { ve } \\
\text { riske } \\
\text { karşı } \\
\text { duyarlı } \\
\text { niteliği }\end{array}$ & $\begin{array}{l}\text { Hesap } \\
\text { verebilir } \\
\text { niteliği }\end{array}$ \\
\hline $\begin{array}{l}\text { Her çocuğun } \\
\text { söz sahibi } \\
\text { olması(Ö1, } \\
\text { Ö2, Ö3,Ö10) }\end{array}$ & $\checkmark$ & $\checkmark$ & $\checkmark$ & $\checkmark$ & $\checkmark$ & $\checkmark$ & & \\
\hline $\begin{array}{l}\text { Bir şey satın } \\
\text { alırken } \\
\text { çocuğun } \\
\text { görüşünü } \\
\text { almak(Ö3) }\end{array}$ & $\checkmark$ & & $\checkmark$ & & $\checkmark$ & & & \\
\hline $\begin{array}{l}\text { Çocuğu } \\
\text { zorlamak } \\
\text { yerine teşvik } \\
\text { etmek (Ö4) }\end{array}$ & & $\checkmark$ & $\checkmark$ & & & & & $\checkmark$ \\
\hline
\end{tabular}




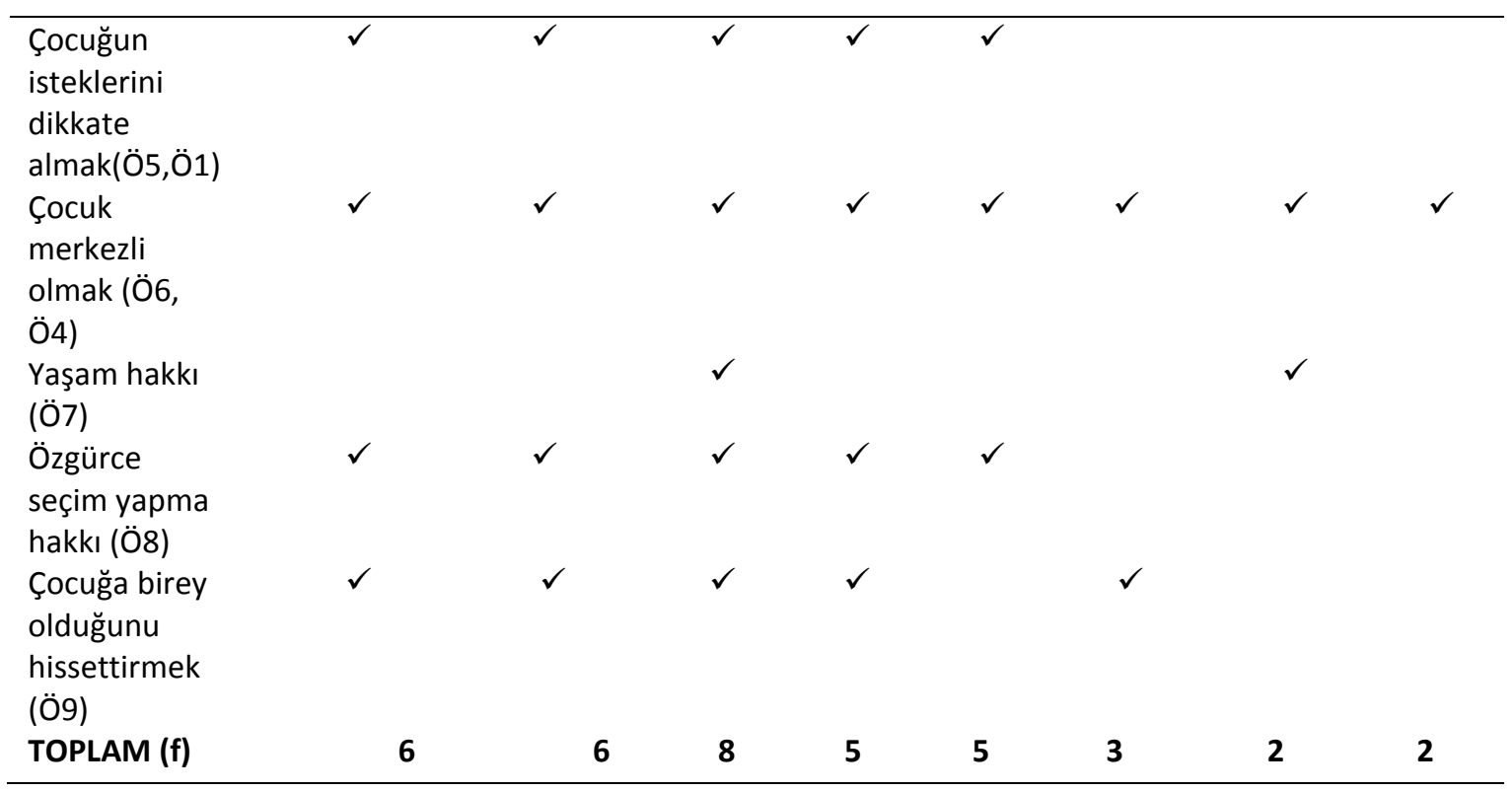

Tablo 1 incelendiğinde, öğretmen görüşlerine göre öğretmenlerin çocuğun katılım hakkını en çok saygılı $(f=8)$ niteliğine göre tanımladıkları görülmüştür. Bunu gönüllü $(f=6)$, şeffaf ve bilgilendirici $(f=6)$ niteliği takip etmiştir. Öğretmenlerin çocuğun katılım hakkına yönelik ifadelerinde en az rastlanan katılım nitelikleri ise güvenli ve riske karşı duyarlı $(f=2)$ ve hesap verebilir $(\mathrm{f}=2)$ nitelikleri olmuştur.

"Çocuğun katılım hakkı özellikle ailede olmalı, çocuğa fikri sorulmalı, ona bir birey olduğu hissettirilmeli Ö9", " ... Çocuğun evde de görüşleri alınmalı, eve bir şey alındığında çocuğa da sorulmalıdır, her şeyde söz sahibi olmalıdır Ö3", "...Çocuk merkezli etkinlikler tercih ediyorum Ö4"

Aşağıdaki tabloda öğretmenlerin çocukların katılım hakkına yönelik sınıf içinde yaptıkları uygulamaları gösteren analiz sonuçlarına yer verilmiştir.

Tablo 2

Öğretmenlerin Çocuğun Katılım Hakkını Sağlamaya Yönelik Neler Yaptıklarına İlişskin Görüşlerinin Katılım Hakkı Niteliklerine Göre Analiz Edilmesi

\begin{tabular}{|c|c|c|c|c|c|c|c|c|}
\hline & & Katılım & lakkı Ni & likleri & & & & \\
\hline & $\begin{array}{l}\text { Şeffaf ve } \\
\text { bilgilendiri } \\
\text { ci niteliği }\end{array}$ & $\begin{array}{l}\text { Gönüll } \\
\text { ü } \\
\text { niteliği }\end{array}$ & $\begin{array}{l}\text { Saygıl } \\
\text { I } \\
\text { niteli } \\
\text { ği }\end{array}$ & $\begin{array}{l}\text { Ilgili } \\
\text { niteli } \\
\text { ği }\end{array}$ & $\begin{array}{l}\text { Çocuk } \\
\text { dostu } \\
\text { niteli } \\
\text { ği }\end{array}$ & $\begin{array}{l}\text { Kapsayı } \\
\text { cı } \\
\text { niteliği }\end{array}$ & $\begin{array}{l}\text { Güven } \\
\text { li ve } \\
\text { riske } \\
\text { karşı } \\
\text { duyarl }\end{array}$ & $\begin{array}{l}\text { Hesap } \\
\text { verebili } \\
r \\
\text { niteliği }\end{array}$ \\
\hline & & & & & & & ' niteliği & \\
\hline $\begin{array}{l}\text { Çocukların fikirlerini } \\
\text { önemsemek(Ö1, } \\
\text { Ö2,Ö10) }\end{array}$ & $\checkmark$ & $\checkmark$ & $\checkmark$ & $\checkmark$ & $\checkmark$ & & & \\
\hline $\begin{array}{l}\text { Çocukların yaparak } \\
\text { yaşayarak } \\
\text { öğrenmelerini } \\
\text { sağlamak(Ö1, Ö3, Ö4) }\end{array}$ & $\checkmark$ & & $\checkmark$ & $\checkmark$ & $\checkmark$ & & & \\
\hline $\begin{array}{l}\text { Günlük planı esnek } \\
\text { tutmak(Ö1,Ö2, Ö4, Ö5, } \\
\text { Ö7,Ö8) }\end{array}$ & $\checkmark$ & & $\checkmark$ & $\checkmark$ & $\checkmark$ & & & \\
\hline
\end{tabular}




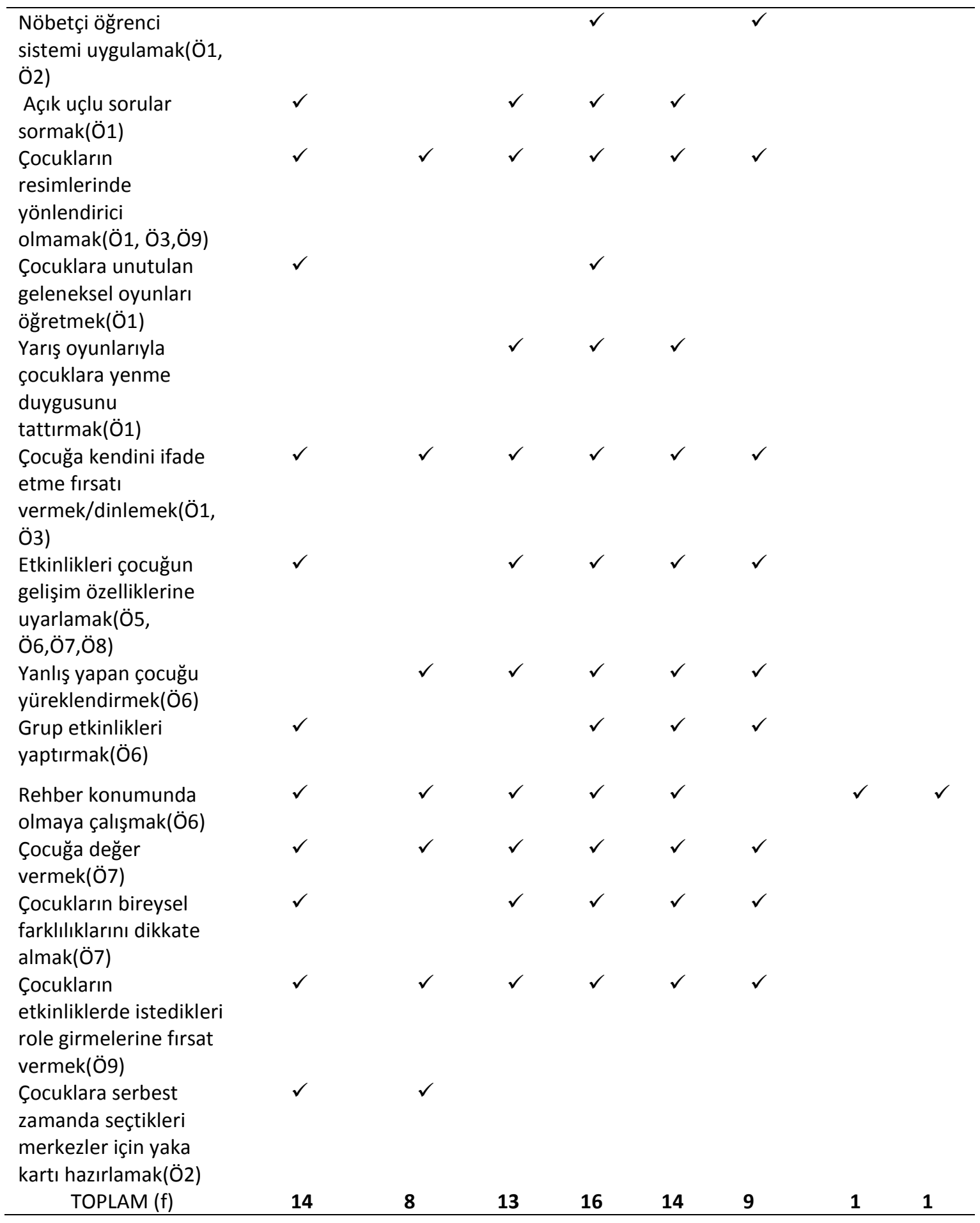

Tablo 2 incelendiğinde, öğretmenlerin görüşlerine göre öğretmenlerin çocuğun katılım hakkını en çok ilgili ( $f=16)$ niteliğine göre tanımladıkları görülmüştür. Bunu şeffaf ve bilgilendirici ve çocuk dostu ( $f=14)$ nitelikleri takip etmiştir. Öğretmenlerin çocuğun katılım hakkına yönelik ifadelerinde en az rastlanan katılım nitelikleri ise güvenli ve riske karşı duyarlı ve hesap verebilir $(f=1)$ nitelikleri olmuştur.

"Çocukları resim yaparken istedikleri rengi kullanmaları için serbest bırakıyorum, baskı yapmıyorum, çok renk kullanmaları konusunda teşvik ediyorum Ö1” , "... Çocuk merkezli plan hazırladığım için rehber konumunda olmaya çalışıorum Ö6", " ... Çocukların isteklerini göz 
önünde bulunduruyorum, bu şekilde çocuklar etkinlikten keyif alıyor Ö2", "...illa şu etkinliği uygulayayım demiyorum, çocukların ilgilerini göz önünde bulunduruyorum Ö5"

Aşağıdaki tabloda, öğretmenlerle yapılmış olan görüşmeler sonucunda, öğretmenlerin sınıf içinde yaptıkları uygulamalarda çocukların katılım hakkını ihlal ettikleri tespit edilen durumlara yer verilmiştir.

Tablo 3

Öğretmenlerin Sınıf İ̧inde Yaptıkları Uygulamalara ilişsin Görüşlerine Göre Çocukların Katılım Hakkını ihlal Ettikleri Belirlenen Durumların Katılım Hakkı Niteliklere Göre Analiz Edilmesi

Sanat etkinliğinde tüm çocukların aynı şeyi yapmasını beklemek(Ö5,Ö8)

Sanat etkinliğinde tek masa hazırlamak.(Ö3,0̈4,Ö5,Ö7,0̈8, Ö9,Ö10)

Sınıftaki tüm çocukları dinleyememek(kalabalıktan dolayı)(Ö5,Ö7)

Etkinliklerde özgüveni yüksek çocuklara öncelik tanımak(Ö4, Ö6) Her çocuğu her etkinliğe katmak(Ö8)

Etkinliklerde az soru sormak(Ö5,Ö7)

Serbest zamanda merkezlerde bulunabilecek çocuk sayısı için kota koymak(Ö2)

Çocukları yapılan her işe dahil etmek(Ö2)

Çocuğun her şeyde söz sahibi olması(Ö3)

\begin{tabular}{llllllll}
\multicolumn{9}{c}{ Katılım Hakkı Nitelikleri } & & & \\
Şeffaf ve & Gönül & Saygı & İlgili & Çocu & Kapsay & Güve & Hesap \\
bilgilendi & lü & lı & niteli & k & ICı & nli ve & verebi \\
rici & niteli & niteli & ği & dost & niteliği & riske & lir \\
niteliği & ği & ği & & u & & karşı & niteliğ \\
& & & & niteli & & duyar & i \\
& & & & ği & & lı & \\
& & & & & & niteli & \\
& & & & & & ği &
\end{tabular}

\begin{tabular}{lllllllll} 
TOPLAM (f) & 9 & 8 & 9 & 9 & 9 & 5 & 2 & 0 \\
\hline
\end{tabular}

Tablo 3 incelendiğinde, öğretmen görüşlerine göre öğretmenlerin çocuğun katılım hakkını en çok ihlal ettikleri saptanan niteliklerin şeffaf ve bilgilendirici, saygılı, ilgili ve çocuk dostu ( $F=9)$ olduğu görülmektedir. Öğretmenlerin çocuğun katılım hakkını ihlal ettiklerini gösteren bazı görüşler şu şeklidedir:

"Her çocuğu her etkinliğe katmayı amaçlıyorum Ö8", "...Çocuklar Türkçe-dil etkinliğinde çok yorum yaptıkları için soru sormalarına müsaade etmiyorum yoksa konu amacından sapıyor Ö5", "...Sınıfta çok pasif öğrenciler var, o yüzden önce özgüveni yüksek olan çocukları drama etkinliğine alıyorum Ö4...", Sınıf mevcudundan dolayı katılım hakkını sağlamak zor oluyor, 
Türkçe dilde zorlanıyorum ilgiyi canlı tutmak zor olduğu için soru sormamaya çalışıyorum Ö7", "Katıım hakkını söz hakkı olarak görüyorum, çocuk her şeyde söz sahibi olmalıdır Ö3", "Bazı merkezler çok kalabalık oluyor o yüzden başta çocukların seçim yapmalarına firsat veriyorum sonra o merkeze ait bir kart takıyorum yakalarına sürekli yer değiştirmesinler diye, daha dengeli dağılım oluyor Ö2"

Aşağıdaki tabloda, çocuklarla yapılan grup görüşmeleri sonucunda çocukların sınıf içi uygulamalarda kullanamadıklarını düşündükleri katılım haklarına yer verilmiştir.

Tablo 4

Çocukların Sinıf İ̧̧i Uygulamalarda Kullanamadıklarını Düşündükleri Katılım Haklarına İlişkin Görüşlerinin Katılım Hakkı Niteliklerine Göre Analiz Edilmesi

\begin{tabular}{|c|c|c|c|c|c|c|c|}
\hline & \multicolumn{7}{|c|}{ Katılım Hakkı Nitelikleri } \\
\hline & $\begin{array}{l}\text { Şeffaf ve } \\
\text { bilgilendirici } \\
\text { niteliği }\end{array}$ & $\begin{array}{l}\text { Gönüllü } \\
\text { niteliği }\end{array}$ & $\begin{array}{l}\text { Saygılı } \\
\text { nitelig̈i }\end{array}$ & $\begin{array}{l}\text { Ilgili } \\
\text { nitelig̈i }\end{array}$ & $\begin{array}{l}\text { Çocuk } \\
\text { dostu } \\
\text { niteliği }\end{array}$ & $\begin{array}{l}\text { Kapsayıcı } \\
\text { niteliği }\end{array}$ & $\begin{array}{l}\text { Hesap } \\
\text { Verebilir }\end{array}$ \\
\hline $\begin{array}{l}\text { Oyun seçimine karar } \\
\text { verememe(Ç1,Ç3,Ç4,Ç7,Ç9,Ç10) }\end{array}$ & $\checkmark$ & $\checkmark$ & $\checkmark$ & $\checkmark$ & $\checkmark$ & & \\
\hline $\begin{array}{l}\text { Serbest zamanı } \\
\text { planlayamama(zaman ve } \\
\text { süre)(Ç1,Ç2,Ç3,Ç6,Ç7,Ç8Ç10) }\end{array}$ & $\checkmark$ & $\checkmark$ & $\checkmark$ & $\checkmark$ & $\checkmark$ & & \\
\hline $\begin{array}{l}\text { Etkinliklerin esnek } \\
\text { olmaması(Ç1,Ç3,Ç9) }\end{array}$ & $\checkmark$ & $\checkmark$ & $\checkmark$ & $\checkmark$ & $\checkmark$ & $\checkmark$ & \\
\hline $\begin{array}{l}\text { Dış mekân etkinliklerine } \\
\text { yeterince yer verilmemesi(gezi } \\
\text { vb.)(Ç1,Ç2,Ç3,Ç५,Ç9,Ç10) }\end{array}$ & $\checkmark$ & $\checkmark$ & $\checkmark$ & $\checkmark$ & $\checkmark$ & & \\
\hline $\begin{array}{l}\text { Yasak olan materyalleri } \\
\text { kullanamama(Ç1) }\end{array}$ & $\checkmark$ & & $\checkmark$ & $\checkmark$ & $\checkmark$ & & 39 \\
\hline $\begin{array}{l}\text { İstendiği zaman resim } \\
\text { yapamama(Ç2,Ç3,Ç4,Ç6,Ç10) }\end{array}$ & $\checkmark$ & $\checkmark$ & $\checkmark$ & $\checkmark$ & $\checkmark$ & $\checkmark$ & \\
\hline $\begin{array}{l}\text { Masa etkinliklerinin daha sıkıcı } \\
\text { ve uzun olması(Ç1,Ç9) }\end{array}$ & $\checkmark$ & $\checkmark$ & $\checkmark$ & $\checkmark$ & $\checkmark$ & & \\
\hline $\begin{array}{l}\text { Etkinliklerin } \\
\text { bitirilmesi/tamamlanması için } \\
\text { zorlanılmak(Ç2,Ç6) }\end{array}$ & $\checkmark$ & $\checkmark$ & $\checkmark$ & $\checkmark$ & $\checkmark$ & $\checkmark$ & \\
\hline $\begin{array}{l}\text { Öğretmenlerin oyunlara } \\
\text { katılmaması(Ç4) }\end{array}$ & $\checkmark$ & & $\checkmark$ & & $\checkmark$ & & \\
\hline $\begin{array}{l}\text { Öğretmen gibi karar } \\
\text { verememek(Ç5) }\end{array}$ & $\checkmark$ & $\checkmark$ & $\checkmark$ & $\checkmark$ & $\checkmark$ & $\checkmark$ & \\
\hline $\begin{array}{l}\text { Her şeye öğretmenlerin karar } \\
\text { vermesi }(C 7, C \zeta 8)\end{array}$ & $\checkmark$ & $\checkmark$ & $\checkmark$ & $\checkmark$ & $\checkmark$ & $\checkmark$ & $\checkmark$ \\
\hline $\begin{array}{l}\text { Etkinliklere katılma } \\
\text { zorunluluğu(Ç10) }\end{array}$ & $\checkmark$ & $\checkmark$ & $\checkmark$ & & $\checkmark$ & & \\
\hline TOPLAM (f) & 12 & 10 & 12 & 10 & 12 & 5 & 1 \\
\hline
\end{tabular}

Çocukların görüşleri dikkate alınarak oluşturulan tabloda, öğretmenlerin sınıf içi uygulamalarının daha çok katım hakkını oluşturan niteliklerden şeffaf ve bilgilendirici, saygılı ve çocuk dostu $(f=12)$ niteliklerini ihlal ettiğini ortaya koymaktadır. şu şekildedir:

Katılım hakkının saygılı ve gönüllük niteliklerinin ihlal edildiğini gösteren çocuk görüşleri 
"...Etkinlerde serbest olmadığımız için sıkılıyorum...Ç1", Ben serbest zamana karar veremiyorum, ne zaman oynayacağıma mesela...Ç3", "...Keşke öğretmenler olmasaydı... daha eğlenceli... o zaman robot yapardık, onları istediğimiz gibi oynatırdık...Ç8", "...Ben öğretmen gibi karar verebilmek isterdim, hep sevdiğim etkinlikleri yaptırırdım o zaman... oyun oynatırdım en çok...Ç5", "...Hikaye çok uzun ve sıkıcı olduğunda dinlemek istemiyorum...Ç10", "Masa etkinliklerinden sıkılıyorum, resim yapmak istiyorum...(Ç2),... "Öğretmenler bize etkinlik planlıyor... bizimle oyun oynasalar keşke... bana resim yapsın...Ç4", "Bahçeye daha çok çıkmak daha güzel olurdu, sıkılmazdım...Ç6"

\section{SONUÇ, TARTIŞMA VE ÖNERILER}

Araştırmanın bulgularına göre, çalışma grubundaki okul öncesi öğretmenlerinin çocuğun katılım hakkı konusunda yeterli bilgiye sahip olmadıkları görülmüştür. Öğretmenler, katıım hakkını daha çok şeffaf ve bilgilendirici, saygılı ve gönüllü niteliklerine göre tanımlamışlar, ancak açıklamalarında güvenli ve riske karşı duyarlı ve hesap verebilir niteliklerini göz ardı etmişlerdir. Çalışmanın sonucunda öğretmenlerin uygulamalar sırasında katılım hakkının niteliklerinden daha çok şeffaf ve bilgilendirici, ilgili ve çocuk dostu niteliklerini kapsadıkları, ancak güvenli ve riske karşı duyarlı ve hesap verebilir niteliklerine daha az yer verdikleri görülmüştür. Öğretmenlerin, çocukların katılım hakkını sağlamaya yönelik yaptıkları uygulamaları anlatırken, katılım hakkının en çok şeffaf ve bilgilendirici, saygılı, ilgili ve çocuk dostu niteliklerini ihlal ettikleri belirlenmiştir. Buna göre, öğretmenler çocuğun katılım hakkının ne olduğu konusunda daha çok katılım hakkı niteliklerinden şeffaf ve bilgilendirici ve saygılı niteliklerine vurgu yapmalarına karşın, öğretmenlerin ve çocukların görüşlerine göre yine en çok bu nitelikler üzerinde ihlaller yaptıkları görülmüştür. Bu durum, öğretmenlerin sınıf içi uygulamalarındaki katılım hakkı ihlallerinin kendileri tarafından fark edilmediğini yansıtıyor olabilir.

Öğretmenler çocuklara verilen seçme fırsatını, çocukların serbest zaman etkinliklerinde istedikleri merkezde yer almaları şeklinde sağladıklarını ifade etmişlerdir. Dolayısıyla, bu durum öğretmenlerin çocukların karar verme sürecini destekleyecek olan, etkinliklerde birden fazla seçenek sunma uygulamalarını yeterince sağlamadıklarını düşündürmüştür. Öğretmenler bu durum için sınıfın kalabalık olması gibi farklı nedenler göstermişlerdir. Ayrıca bir öğretmen "Katılım hakkını söz hakkı olarak görüyorum, çocuk her şeyde söz sahibi olmalıdır Ö3" ifadesini kullanmıştır. Bu ifadenin ÇHS 12. Maddesinde yer alan "çocuğun kendini ilgilendiren her konuda, yaşı ve olgunluk derecesine uygun olarak" söylemiyle uyuşmadığı görülmektedir. Dolayısıyla çocukların kendilerini ilgilendirmeyen konularda karar vermelerini beklemek de çocukların katılım hakkına uygun düşmeyen bir yaklaşım olmaktadır.

Koran (2012) yaptığı çalışmada, okul öncesi öğretmenlerin çocuğun katılım hakkını sağlayan uygulamalara yer vermekle birlikte çeşitli nedenlerden dolayı çocukların katılım hakkını ihlal eden uygulamalara sahip olduklarını belirlemiştir. Çalışma kapsamında çocukların katılım hakkının ihlal edilme sebeplerinin, öğretmen merkezlilik, sen dili kullanmak, otokratik ve geleneksel öğretmen özelliklerine sahip olmak, öğretmenlerin duygusal ve fiziksel istismar içeren davranışları ve çocuklar arasında ayrımcılık yapmaları olduğu tespit edilmiştir.

Illköğretim kademesinde de çocuğun katılım hakkına yönelik araştırma sonuçları okul öncesiyle benzerlik göstermektedir. Uçuş ve Şahin'in (2009), ilköğretim kademesinde görev yapan öğretmenlerle gerçekleştirdikleri çalışmalarında öğretmenlerin çocuğun katılım hakkı ile ilgili yeterli bilgiye sahip olmadıkları, ders programında ele alınan konuların dışında, doğrudan çocuğun katılım hakkını sağlamaya yönelik uygulamalara yer vermedikleri görülmüştür. 
Gürkan ve Koran (2015)'ın okul öncesi eğitim programında katılım hakkını inceledikleri çalışmalarında, tüm gelişim alanları ile ilgili kazanımlarda, katılım hakkının niteliklerinden en çok vurgulananların "ilgili, gönüllü ve kapsayıcı" nitelikleri olduğu, en az yer verilen niteliklerin ise "şeffaf ve bilgilendirici, hesap verebilir, eğitimle desteklenmiş, emniyetli ve riske karşı duyarlı" nitelikleri olduğu tespit edilmiştir.

Araştırmanın bir diğer bulgusuna göre, çocuklarla yapılan görüşmeler sonucunda öğretmenlerin katılım hakkının niteliklerinden en çok şeffaf ve bilgilendirici, saygılı ve çocuk dostu niteliklerini göz ardı ettikleri tespit edilmiştir. Görüşmeler sırasında çocukların taleplerinin daha çok, etkinliklere katılım konusunda özgür olmaları, yapılandırılmış etkinliklerin daha az olması, serbest zaman etkinliklerinin daha uzun planlanıp öğretmenlerinin de oyunlarına katılması yönünde olduğu belirlenmiştir. Çocuklarla yapılan görüşmelerde on çocuktan sekizi "Öğretmenler ne yapar?" sorusuna "Bize etkinlik hazırlarlar" şeklinde cevap vermişlerdir. Bunun yanı sıra çocuklara, öğretmenlerden beklentileri sorulmuş çocuklar bu konudaki görüşlerini, "Bizimle oyun oynasın, etkinlik için beni zorlamasın, daha çok serbest zaman planlasın" şeklinde belirtmişlerdir. Çocukların ifadelerinden anlaşıldığına göre, çocuklar sınıf içi uygulamalarda daha çok söz hakkına sahip olmayı istemekteler ve kararlarının sınıf içi uygulamalar için belirleyici olmasını talep etmektedirler. Mamur Işıkçı (2015), doktora tezi kapsamında yaptığı alan araştırmasında orta öğretime devam eden öğrencilere, talep ettikleri haklara yönelik bir makale yazdırmış ve buna ilişkin çocukların görüşlerini almıştır. Öğrencilerin katılım hakkına yönelik bazı görüşleri şu şekildedir: "Okulda, evde, sokakta zamanımızı nasıl geçireceğimizi anne, baba ve yine öğretmenlerimizin yardımı ile kararlaştıralım... Çocuk oyuncaklarından, elbise, yiyecek, içecek seçimine kadar birçok şeyi beraber karar vererek almalıyız... Gençlere ve çocuklara 'sus sen küçüksün!' sözünün söylenmesinin yasaklanmasını isterdim... Çocuk deyince aklıma hiç hak verilmeyen, dinlenmeyen, konuşturulmayan biri aklıma geliyor..." Çalışmanın bulgularından anlaşıldığı gibi büyük yaş grubundaki çocukların talepleri ile küçük yaş grubundaki çocukların katılım hakkına yönelik görüşleri benzerlik göstermektedir. Buna göre, çocukların yetişkinler tarafından dikkate alınmak ve onları ilgilendiren konularda dinlenilmek istedikleri görülmektedir. Çocuk hakları sözleşmesinin 12. Maddesinde geçen "kendi görüşlerini oluşturma kabiliyetine sahip" ifadesi de çocukların bu taleplerini yansıtmaktadır. Bu maddede çocuğun kendi görüşlerini ifade etme hakkı için hiçbir yaş sınırı getirilmediği, çocuğun sözsüz iletişim biçimlerinin tanınması ve bunlara saygı gösterilmesi gerektiği vurgulanır (BM ÇHK, 2009).

Araştırmanın sonucunda çocukların görüşlerine göre, serbest zaman etkinliklerinden daha çok keyif aldıkları, etkinliklere gönüllü olarak katılmak istedikleri ve oyunlarını öğretmenleriyle oynamalarının onlar için daha keyif verici olduğu söylenebilir. MEB Okul öncesi eğitim programına (2013) ait özellikler de çocukların görüşlerini destekler niteliktedir. Programın bazı özellikleri şu şekildedir: Programa göre, öğrenme merkezleri önemlidir. Merkezler, iç mekânlarda olduğu kadar dış mekânlarda da düzenlenmelidir. Yakın çevre olanakları eğitim amaçı kullanılmalıdır. Program oyun temellidir, esnektir ve çocuk merkezlidir. Programa ait belirtilen özelliklerin çocukların talepleriyle örtüştüğü görülmektedir.

Erbay (2013), çalışmasında, aileleri, profesyonelleri ve kurumları çocuğun katılım hakkına alıştırmanın kolay olmadığını, ayrıca çocuğun katıım hakkının, çocuğa bakış, değer ve kültür sorunu olduğunu vurgulamıştır. Bir okul öncesi öğretmeninin sahip olması gereken birçok özelliğin (okul öncesi eğitim programları konusunda bilgili olmak, çocukça davranışlardan sıkılmamak, yaratıcı olmak, iyi bir rehber olmak, meslektaşları ve aileler ile işbirliği yapabilmek (Okay, 1999)), çocukların katılım hakkını doğrudan etkileyeceği düşünülmektedir. Bu konuda yapılan araştırmalar da çocuğun katılım hakkının sağlanmasında öğretmene ait özellkilerin önemini ortaya koymuştur (Özyıldırım (2007). 
Şahin ve Polat (2012), ise çocuğun katılım hakkının nasıl olması gerektiğini şu şekilde özetlemiştir: Çocuğun "kendi" görüşlerini ifade edebilmesi için kendini güvende hissettiği bir ortam yaratılması, çocuğun karar alacağı konuda ebeveyni veya vasisi tarafından bilgilendirilmesinin sağlanması, görüşlerini ifade edeceği şartlar hakkında aydınlatılmasının sağlanması, çocuğun yaşı ve olgunluğuna bağlı olarak kendi anlayışlarını, tercihlerini ve seçimlerini sergiledikleri oyun, vücut dili, yüz ifadeleri ile çizim boyama dahil sözsüz iletişim biçimlerinin tanınması, çocuğun manipüle edilmemesi, uygunsuz etki ve baskıya maruz bırakılmaması, engelli çocukların görüşlerini ifade edebilmeleri için gerekli koşulların sağlanması, bununla birlikte azınlık veya göçmen çocuklarının ve çoğunluğun dilini konuşamayan çocukların görüşlerini ifade edebilmeleri için ortam yaratılması şeklinde ifade etmiştir. Çocuğun kendisini ilgilendiren konularda görüşünü bildirme hakkını gereği gibi kullanabilmesi için her şeyden önce sağlıklı bir görüş oluşturabilmesi gerekmektedir. Bunun için de kendisinin konu hakkında bilgilendirilmesi ve aydınlatılması şarttır (Serozan, 2005). Dolayısıyla bu durum, katılım hakkı niteliklerinden şeffaf ve bilgilendirici niteliği ile örtüşmekte olup öğretmenlerin, çocukların görüşlerini sağlıklı bir şekilde ifade etmelerine olanak sağlayan bu niteliği etkili bir şekilde uygulamaları gerekmektedir. Yapılan çalışmalar, Türkiye'de çocuğun kendi ile ilgili karar verme süreçlerinde yer aldığına ilişkin bir yönelim olmakla birlikte geleneksel uygulamaların varlığını sürdürdüğünü göstermektedir (Akyol, 2011; Koran, 2012).

Çocuk hakları sözleşmesinde sıralanan çocuk hakları son değerlendirmede tipik insan haklarıdır. Çocuklar en başta insandırlar. Sözleşmenin dökümünü yaptığı çocuk haklarında, insan hakları sadece yinelenmez, aynı zamanda pekiştirilir (Serozan, 2005).

Araştırmanın sonuçları dikkate alınarak şu önerilerde bulunulabilir:

$\checkmark$ Sınıfta uygulanan etkinlikler çocukları doğrudan ilgilendirdiğinden planlama ve uygulama aşamasında çocukların görüşleri öğretmenler tarafından dikkate alınmalıdır.

$\checkmark$ Serbest zaman etkinliklerinde olduğu kadar, diğer etkinlik süreçlerinde de çocuklara seçme fırsatı verebilecek etkinlikler planlanmalıdır (sanat etkinliğinde birden fazla masa hazırlanması vb.)

$\checkmark$ Çocukları daha iyi anlamak için özellikle serbest zaman etkinliklerinde çocukların oyunlarında katılımcı gözlemci olarak yer almak katılım hakkının uygulanmasına katkı sağlayabilir.

$\checkmark$ Bu konuda çalışma yapacak araştırmacılar, okul öncesinde katılım hakkı uygulamalarını daha iyi değerlendirebilmek için günlük planlarda yer alan etkinlikleri inceleyebilir ve sınıf içi gözlemlerle destekleyerek alana katkı sağlayabilirler.

$\checkmark$ Çocuklara yönelik yürütülecek projelerde çocuk katılımcılara yer verilerek çocukların ihtiyaçlarının, taleplerinin daha net anlaşılması sağlanabilir. Bu yolla, zenginleştirilmiş fikirler ile çocukların yararını en üst seviyede gözeten daha etkili projeler ortaya çıkartılabilir.

\section{KAYNAKÇA}

Acar, H. (2003). Türkiye'de çocuk olmak ve eğitim sistemi üzerine düşünceler. KASYÖDER

Aylık Kültür Dergisi, 1(4), 9-10.

Akyol, S.(2011). Çocuk Hakları'na Dair Sözleşme çerçevesinde çocuğun görüşlerime saygı ilkesi

(varlığının sahibi olan çocuk). 1. Türkiye Çocuk Hakları Kongresi Yetişkin Bildirileri Kitabı, 183-188. İstanbul: Çocuk Vakfı.

Akyüz, E. (2001). Çocuk hakları sözleşmesinin temel ilkeleri ışığında çocuğun eğitim hakkı. Milli

Eğitim, 151, 24-33. 
Akyüz, E. (2013). Çocuk Hukuku. Ankara: Pegem Akademi.

Alderson, P. (2000). Young Children' Rights: Exploring Beliefs, Attitudes, Principles and Practice, London: Jessica Kingsley Publishers.

Birleşmiş Milletler Çocuk Hakları Komitesi, (2009). Çocuk haklarına dair sözleşme genel yorum no: 12 çocuğun dinlenilme hakkı. Cenevre: Elli Birinci Oturum. http://www.cocukhaklariizleme.org/wp-content/uploads/GCs-11-12-13-2008-2011.pdf adresinden 03. 04. 2016 tarihinde indirilmiştir.

Creswell, J. W. (2014). Araştırma Deseni. (Selçuk Beşir Demir, Çev. Ed.), Ankara: Eğiten Kitap.

Çokluk, Ö., yılmaz, K., Oğuz, E. (2011). Nitel Bir Görüşme Yöntemi: Odak Grup Görüşmesi. Kuramsal Eğitimbilim, 4 (1), 95-107.

Erbay, E. (2013). Çocukların katılım hakkı üzerine bir Türkiye değerlendirmesi, insan ve Toplum Bilimleri Araştırmaları Dergisi, 2(1), 38-54.

Family Health International. (2009). Guidelines for promoting child participation. Namibia Einarsdottir, J. (2007). Research with children: methodological and ethical challenges. Early Childhood Education Research Journal. Vol.15(2), 198-211.

Gürkan, T., \& Koran, N. (2014). 36-72 Aylık Çocuklar İçin Okul Öncesi Eğitim Programının Çocuğun Katılım Hakkına Yer Verme Durumu Açısından Incelenmesi. Journal of Teacher Education and Educators, Vol. 3(2), 203-226.

Hart, S. N. \& Hart, B. W. (2014). Children's rights and school psychology: Historical perspective and implications for the profession. School Psychology International, Vol. 35(1) 6-28.

İnal, K. (2014). Çocuk ve demokrasi. İstanbul: Ayrıntı.

Karasar, N. (2002). Bilimsel araştırma yöntemi (11.Baskı). Ankara: Nobel.

Koran Güner, N. (2015). Çocuğun katılım hakkı ve materyal yapım, seçim ve kullanım süreçlerine çocuğun aktif katılımı. N. Avcı (Ed.), Okul öncesinde materyal geliştirme, (s.31-38) Ankara: Hedef.

Koran, N. (2012). Okul öncesi öğretmenlerinin çocukların katılım hakkı konusundaki uygulamalarının öğretmen adayı gözlemlerine göre incelenmesi. Yüksek lisans tezi, Girne Amerikan Üniversitesi, Girne. https://www.academia.edu/ adresinden 06. 05. 2016 tarihinde indirilmiştir.

Hart, N. S. (2007). Making sure the child's voice is heard. International Review of Education, 4(3), 251-258.

Johnson, B. \& Chtistensen, L. (2014). Eğitim araştırmaları. (Selçuk Beşir Demir, Çev. Ed.). Ankara: Eğiten Kitap.

Lansdown, G. (2005). Çocukların gelişen kapasiteleri. Birleşmiş Milletler Çocuk Fonu Italya: UNICEF.

Mamur Işıkçı, Y. (2015). Çocuk gözüyle Türkiye'de çocuk hakları sorunu. Ankara: Hegem. 
Mayall, B. (2000) Conversations with children: working with generational issues, in: P.

Christensen \& A. James (Eds)Research with children(New York, Falmer Press), 120-135

Milli Eğitim Bakanlığı. (2013). Okul öncesi eğitim programı. Ankara: MEB.

Merriam, S. B. (2013). Nitel Araştırma. (Selahattin Turan, Çev. Ed.). Ankara: Nobel.

Miles, M. B., \& Huberman, A. M. (2015). Nitel veri analizi. (Sadegül Akbaba Altun \& Ali Ersoy, Çev. Ed.). Ankara: Pegem.

Oktay, A. (1999 a). Yaşamın Sihirli Yılları: Okul Öncesi Dönem. İstanbul: Epsilon Yayıncılık.

Özdemir, H., Ruhi, A, C. (2012). Çocuk hukuku. Ankara: Adalet.

Özer, Y. E. (2013). Çocuk hakları, katılım ve yerel düzeyde uygulaması: Türkiye örneği, C.Ü. iktisadi ve Idari Bilimler Dergisi, 14 (1), 245-258.

Özyıldırım, T. (2007). Ankara ili ilköğretim okulu öğrencilerinin katılım hakkını kullanma durumlarına ilişkin sınıf öğretmenlerinin görüşleri. Yüksek lisans tezi. Ankara Üniversitesi, Eğitim Bilimleri Enstitüsü, Eğitim Bilimleri Anabilim Dalı, Eğitim Yönetimi ve Teftişi Yüksek Lisans Programı. Ankara.

Parkinson, D. D. (2001) Securing trustworthy data from an interview situation with young children: six integrated interview strategies, Child Study Journal,31(3), 137-156.

Patton, M. Q. (2014). Nitel araştırma ve değerlendirme yöntemleri. ( Mesut Bütün \& Selçuk Beşir Demir, Çev. Ed.) Ankara: Pegem Akademi

Serozan, R. (2005). Çocuk hukuku. İstanbul: Beta.

Şahin, S. \& Polat, O., (2012). "Türkiye"de ve dünyadaki gelişmiş ülkelerde çocuk katılım hakkı algısının ve uygulamalarının karşılaştırı ması". Hukuk ve iktisat Araştırmaları Dergisi, 4, 275-282.

TED. (2007). TÜRKIYE'DE okul öncesi eğitim ve ilköğretim sistemi temel sorunlar ve çözüm önerileri. (Çev. Ed. Servet Özdemir, Hasan Bacanlı \& Murat Sözer). Türk Eğitim Derneği, 1. Basım.

Tüzün, I. Sarışık, Y. (2015). Türkiye'de okullarda çocuk katılımı: Durum analizi. İstanbul Bilgi Üniversitesi Çocuk Çalışmaları Birimi- Eğitim Reformu Girişimi Demokratik Okullara doğru Projesi Kitapları-No.1 http://cocuk.bilgi.edu.tr/wpcontent/uploads/2015/06/DOD_DAR_kitap_baski.pdf adresinden 10. 09.2016 tarihinde indirilmiştir.

Uçuş, Ş., Şahin, A. E. (2009). Çocuk hakları sözleşmesine yönelik öğretmenlerin ve okul yöneticilerinin görüşleri. Adnan Menderes Üniversitesi Eğitim Fakültesi Eğitim Bilimleri Dergisi, 3(1), 25-41.

Unicef. (2004) Çocuk haklarına dair sözleşme. UNICEF, Türkiye . http://www. cocukhaklari. gov.

tr/condocs//mevzuat/cocuk_haklari_sozlesmesi. pdf, adresinden 03. 03. 2016 tarihinde indirilmiştir.

Unicef. (2009). Dünya çocuklarının durumu. Unicef (Özel Sayı), Kasım.

Yıldırım, A. \& Şimşek, H. (2013). Sosyal Bilimlerde Nitel Araştırma Yöntemleri. Ankara: Seçkin. 
Yıldııım Doğru, S. S., Durmuşoğlu saltalı, N., Budak, O., \& Konuk Er, R. (2012). Çocuk hakları ve koruma: Aile refahı ve koruma, (Çev. Ed. Sunay Yıldıım Doğru). Ankara: Eğiten Kitap.

Williams, E. (2004). Children's Participation and Policy Change in South Asia, Chip Repot No. 6 , London.

Woodhead, M. (210). A Handbook of children and young people's participation(Ed. Barry Percy Smith, Nigel Thomas). New York: Roudledge. 


\section{SUMMARY}

Although right of child deserves to be handled in the concept of human rights; it is a universal concept used to describe all of the rights of children from all around the world such as education, healthcare, housing rights as well as rights of protection against physical, psychological, and sexual abuse. With the convention adopted by the General Assembly of the United Nations on 28 November 1989 the aim was protecting children's rights, and it has been ruled that the states parties must strictly abide by the contract articles (Acar, 2003; Yıldırım Doğru, 2012). The following $12^{\text {th }}$ article of the convention about the child's right of participation: "States Parties shall assure to the child who is capable of forming his or her own views the right to express those views freely in all matters affecting the child, the views of the child being given due weight in accordance with the age and maturity of the child."(Unicef, 2004). According to the United Nations Committee on the Rights of Child school environment is one of the places where a child's right of participation should be encouraged (Erbay, 2013). In this respect the purpose of the researcher was to evaluate the right of participation of children to the applications in classes of preschool institutions, based on the qualifications of right of participation.

In this study the qualitative research method was adopted and case study design was used. In this study ten teachers' and ten children's views towards right of participation were investigated. The participants of the study were composed of two kindergartens one of them is in the center of Kırklareli, the other one is in the center of Ankara. The data for this study were gathered from ten preschool teachers working at these two institutions and ten children from 6 years age group. The teachers and children who participated in this study were selected according to homogeneous sampling method. The data for this study were collected from teachers through semi-structured interviews and children through focus group interviews. The interview sessions were conducted with individual teachers and the sessions were audio recorded. Some of the teachers were not willing to be recorded; therefore, the sessions with those teachers were noted down by the researcher. The interviews with teachers took 15 minutes in average. The interviews were conducted as focus group interviews with children. Children participated in the interviews as pairs. Each interview session with children were conducted with two children who were close friends.

The data collected through interview technique were analyzed through descriptive analysis method. First step was the coding of the data. The categories for coding and a descriptive analysis framework were developed based on the qualifications that need to be in all of the processes of child's participation as stated in The Rights of the Child General Comment No.12 (UN CRC, 2009). Based on this framework, the data gathered from teachers were analyzed according to the qualifications as; transparent and informative, volunteer, respectful, relevant, child friendly, inclusive, safe and sensitive to risk, and accountability.

The findings of the study revealed that preschool teachers participated in this study did not have sufficient information on the child's right of participation. Teachers described the right of participation mostly with transparent and informative, respectful, and volunteer qualifications; however, safe and sensitive to risk, and accountability qualifications were disregarded in their explanations. At the end of the study it was found out that teachers mostly included transparent and informative, relevant, and child friendly qualifications in their applications, while they included safe and sensitive to risk, and accountability qualifications less. In this regard, while the teachers are reporting their applications towards enabling child's right of participation, they mostly violated the transparent and informative, respectful, relevant, and child-friendly qualifications. Based on this, while the teachers highlighted transparent and informative, and respectful qualifications in their explanation of what are the children's right of participation, it was revealed that these qualifications are the most violated ones by teachers.

According to another finding of the study, as a result of the interviews with children it was revealed that the most disregarded qualifications of child's right of participation were transparent and informative, respectful, and child friendly. At the end of the interviews it was found out that children mostly wanted freedom in participation in the activities, smaller number of structured activities, longer free time activities, and teachers' participation to the games. 
Considering the findings of the study the following suggestions can be stated;

$\checkmark$ The activities applied in the classroom directly effects children, therefore children's views should be considered during planning and application

$\checkmark$ As in the free time activities, teachers should plan other activities to provide options for children (such as preparing more than one table in the art activities)

$\checkmark \quad$ In order to understand the children better teachers should take part in their free time activities as participant observer, this can contribute to the application of the right of participation

$\checkmark \quad$ Children should be included as participants in the projects which targets children, in this way a clearer understanding of the needs and demands can be enabled. By so doing enriched ideas and more effective projects which consider children's utmost benefits can be produced. 